\title{
AN ANALYSIS ON CODE-SWITCHING AND MIXING AMONG ENGLISH LEARNERS OF GAYONESE-SPEAKING STUDENTS
}

\author{
Imam Munandar ${ }^{1}$, Ramadhani Sukria ${ }^{2}$ \\ 1,2IAIN Takengon, Aceh Tengah, Aceh, Indonesia \\ Email: imameducator@gmail.com ${ }^{1}$,sukria_rama@gmail.com ${ }^{2}$
}

\begin{abstract}
This research tries to find out types and their dominance of code-switching and code-mixing among EFL students with Gayonese backgrounds. This research also looks at whether a certain type of ethnic group is affluent to a specific type of code-switching and mixing. The employed method is a qualitative study, in which this study manages to identify a social phenomenon in a certain community. The data is obtained from the 13 participants in their conversations. Instruments used are observation, recording, transcribing to identify code-switching, and mixing. The result of this study shows that the participants, who are all entitled to Gayonese identity, employed all kinds of code-switching and mixing, which were extra-sentential, inter-sentential, and intra-sentential. All types of code-switching and mixing are apparent in all sets of conversations. Along with some previous research, this study affirms that there is little evidence that a certain type of ethnicity employs a certain dominant form of code-switching and mixing. There appear all types of code-switching and mixing, without one dominant type, is found in all sets of conversations. Thus, code-switching and mixing were believed to assist the learners to deliver them through to be completely understood and meaningful in the communication.
\end{abstract}

Keywords: Code-switching, Code-mixing, EFL learners, Sociolinguistics

Abstrak: Penelitian ini mencoba untuk mengetahui jenis dan dominasi alih kode dan campur kode bahasa di kalangan mahasiswa EFL yang berlatar belakang Gayo. Penelitian ini juga melihat apakah suatu suku bangsa tertentu cenderung terhadap jenis alih kode dan campur kode tertentu. Metode yang digunakan adalah penelitian kualitatif, dimana penelitian ini berhasil mengidentifikasi suatu fenomena sosial dalam suatu komunitas tertentu. Data tersebut diperoleh dari 13 partisipan dalam percakapan mereka. Instrumen yang digunakan adalah observasi, pencatatan, transkripsi untuk mengidentifikasi alih kode dan campur kode. Hasil penelitian ini menunjukkan bahwa para partisipan yang semuanya berlatar belakang suku Gayo melakukan berbagai macam alih kode dan campur kode; yang semuanya bersifat ekstrasentential, intersentential dan intrasentential. Semua jenis alih kode dan campur kode terlihat dalam semua rangkaian percakapan. Seiring dengan beberapa penelitian sebelumnya, penelitian ini menegaskan bahwa ada sedikit bukti bahwa jenis etnis tertentu menggunakan bentuk dominan tertentu dari alih kode dan pencampuran bahasa. Tampaknya semua jenis alih kode dan campur kode, tanpa satu jenis dominan, ditemukan di semua rangkaian percakapan. Dengan demikian, alih kode dan campur kode diyakini dapat membantu peserta didik menyampaikan olah pikirnya agar benar-benar dipahami dan bermakna dalam komunikasi.

Kata Kunci: Alih kode, Campur kode, peserta didik EFL, Sosiolinguistik.

\section{INTRODUCTION}

Ayeomoni pointed out that code-switching is the mixing of words, phrases, and utterances from two different grammatical or subsystems across utterances boundaries within a similar speech event (Ayeomoni, 2006). Furthermore, she elaborated that it is a symptom of code-switching using language for changing the situation. A slight contrast view is proposed by Hymes (Johnstone \& Marcellino, 2010). She stated that codeswitching could occur between languages by means that the code transfer not only takes place between languages but can also occur between a wide variety of styles that are in a language. Meanwhile, another definition is explained by Susan mentioned that codeswitching is "a communication strategy used to build, cross or ruin social boundaries, to 
create, evoke or change interpersonal relations with their rights and obligations" (Nilep, 2006).

Meanwhile, code-mixing is defined as the insertion of a variety of linguistic features, namely affixes (bound morphemes), lexis (unbound morphemes), phrases, and clauses from an intertwined activity in which the participants, with the purpose of inferring the intention, need to reconcile what they hear to what they comprehend (Perry et al., 1979). He also believed that code-mixing is the switch occurring within a sentence. Moreover, Spolsky described that this code states that interference occurs on the immigrants who often use many words of their new language by using their old language (Nooyen, 1999). Poplack classified code-switching into three categories. They are extrasentential and inter-sentential as well as intra-sentential (Mabule, 2015). He defined Extra-sentential Switching as "the embedding of tag features from a language into a monolingual discourse in another language". The following example shows extrasentential code-switching in the Indonesian language.

Father: Kamu sudah memberesi semua mainannya, good job!

(You have to tidy up your toys).

CEO:Kalau sudah selesai laporannya silakan di presentasi besok, okay?

(If you have finished the report, you may present it tomorrow).

The utterances above explain the insertion of the English language embedded into the Indonesian language. The next kind of code-switching is Inter-sentential. Al-Heeti \& Al-Abdely point out that Inter-sentential code-switching "includes switching at the sentential border in which one clause or utterance is in one language, and the next clause or sentence is in the other" (Al Heeti \& Al Abdely, 2016). Meanwhile, it also means "inter-sentential switching happens when a talker switches from one language to another between different sentences" (Yusuf et al., 2020). It can be concluded that inter-sentential switching takes place beyond the sentence. The following utterance is an example of inter-sentential switching berbeda.

Aku perlu berpergian keluar negeri supaya bisa mengenal budaya-budaya yang

I need to travel overseas so I can meet people from different cultures.

The final type of code-switching is called Intra-sentential. Mabule believed that Intra-sentential code-switching is "marked by a changing from one language to another language within one single utterance"(Mabule, 2015). This sort of code-switching exists inside an utterance. The following utterance is a sort $\mathrm{f}$ Intra-sentential code-switching.

Counsellor: "Setiap orang tua perlu mempelajari how to be great parents?".

Every parent needs to learn how to be great parents.

Multilingual, or at least bilingual English foreign language learners, are believed to switch or mix to other languages when they encounter other multilingual/bilinguals who share the common ethnic group or social upbringing (Mujiono et al., 2013). Trisnawati in her study, has found that Bilinguals are highly likely to switch to an ethnic language for self-identification within the group members; interestingly, this can still happen although they are not sufficiently proficient in that language (Trisnawati, 2017). 
Similarly, bilinguals from a similar social identity are likely to change language in addressing one another to appear respectful. For instance, instead of saying Hello or Hi, in an international university, a Chinese student changes to the Mandarin language whenever s/he meets other Chinese-looking students from any country. In this sort of setting, Intra-sentential code-switching is usually employed. This aims to look respectful and address other students who share the same identity as her/him as Chinese (Nooyen, 1999).

Code-switching and code-mixing can appear not only in a social setting but also happens in an educational setting. Many bilinguals switch or mix the language while being immersed in the educational process (Sugiantari, 2018). EFL students and lecturers usually employ code-switching in the classroom to show their upbringing prestige for they can communicate in English (Susidamaiyanti, 2018). Sadhigian, Rahmi have found that students at the university will say, "Besok kelas kita ada midterm test. Porsinya 50 persen dari total score". This seemingly describes that students employ code-switching to exhibit to other people that they possess English ability and thus what is considered as self-pride and prestige (Sadighian \& Rahimi, 2011).

Nerghes explained another purpose of code-switching. She said that codeswitching is used to make sure that they deliver ideas or through to each other when speaking properly (Wahyu et al., 2016). This is done to make sure that his/her idea is understood by the listener. Also, Bilinguals believe when it comes to conveying strong arguments, code-switching can be an effective strategy by which important thought can be better delivered that results in systematic processing of information. Similarly, Al Hayek shows that the motivation that drives bilinguals to switch language is that they assume some ideas or thoughts are more meaningful and understandable to be delivered in a certain language (Salah \& Hayek, 2016).

The purpose of this current research in to find out and analyze the types of code-switching existing in communication among Gayonese speakers who are learning English at university setting. After that, the result is expected to show the most prominent type and also the least type of code-switching found in the interaction. Bista has showed that code-switching often happens among the same group of students who are learning a foreign language (Bista, 2010). On the basis of this, the current researcher would like to explore the prominent code-switching existing among Gayonese students who are learning English as a foreign language.

\section{LITERATURE REVIEW}

The function of code-switching has been analyzed by some researchers. Trisnawati has demonstrated that EFL learners have a tendency to switch to another language when they encounter other bilinguals who share the same ethnic or social background. In this case, bilinguals' code-switching is aimed at switch to expressing their identification with the group members (Trisnawati, 2017). Furthermore, she illustrated that bilingual sharing the same background often switch code to address each other to highlight their respect. Namely, in an international university, a Moslem student switches to the Arabic whenever s/he meets other Moslem students from any countries; by offering "Assalamu,,alaikum, how are you?" rather than saying "Hello" to respect and address those students who are Moslem. In many cases, intrasentential code-switching is employed. 
There has been an amount of research carried out regarding code-switching and code-mixing. Mukti, in his study named interaction in bilingual and multilingual society research, analyzed speech community in Johar market Semarang (Mujiono et al., 2013). Particularly, she analyzed communication between the seller and the buyer. She found that most of the participants had mastered the Java language because that language was firstly ruled (mother tongue). The Indonesian language was used by sellers to communicate to address respect and in honor of buyers, as seen from the social status or terms of appearance.

A similar study was conducted by Maryam. She identified that there were two kinds of code-switching utilized by English Department students at the University of Sumatera Utara year 2018, called inter sentential Switching and Intra sentential Switching. She also analyzed that the students predominantly employed intra-sentential switching $(82.8 \%)$. The sorts of code-mixing identified were word insertion, hybrid insertion, phrase insertion, and reduplication insertion. The most prominent code-mixing that was used is word insertion (Masna, 2020).

Another research observing code-switching and mixing among bilingual EFL students was conducted by Wijayanti. She examined code-switching phenomena between college students of Sampoerna University. The study tried to find out the students' motivation to switch their language from one into another or vice versa. She found out that students in switching their code were triggered by two reasons, called internal reason, namely their selection of the first language, and external reason, namely putting the hearer in mind (Wijayanti, 2014) .

Still, code-switching-related studies within the EFL context were investigated by Khaerunnisa. She concluded that code-switching among teachers functions as a helpful strategy in delivering effective thought to students (Khaerunnisa, 2016). Another study relevant to code-switching was also carried out at the level of secondary school. It pointed out that code-switching was not only made use by students but also by teachers. It was revealed that teachers maintained and shared a positive attitude that the use of code-switching in the EFL classroom helps contribute to effective classroom interaction (Suganda et al., 2018).

As indicated earlier, it becomes obvious that code-switching is therefore used by both teachers and students to achieve more meaningful and effective classroom communication. Similarly, it is strongly argued that code-switching is employed by teachers and students to convey their thought or perception during the English teachinglearning process (Horasan, 2014). Moreover, Bista finds that majority of bilingual learners in the classroom switch the language to prevent their lack of competence in the foreign language they are learning (Masna, 2020). To sum up, code-switching often takes place in an educational context such as school and university.

\section{RESEARCH METHODOLOGY}

This current research used a qualitative approach. By definition, qualitative research refers to an approach that is employed to analyze and figure out the meaning component or a set of groups associated with a social or human phenomenon (Cresswell, 2014). The 
population of this study is 34 students of Speaking class studying at IAIN Takengon. Meanwhile, there are five randomly selected participants as the research sample. In obtaining data, the researcher conducted an observation and then recorded as well as transcript the conversation taking place naturally among the observed students. Furthermore, the recorded conversation is transcribed into written form to get information as deep as possible. Also, this type of transcription is useful since it gives the researcher opportunity to highlight the occurring code-switching and code-mixing among the participants (Mujiono et al., 2013). The conversation was supposedly and fully recorded and took place naturally without preliminary notification from the researcher. This is done so that the participant can deliver their perceptions and though naturally and extensively (Mubarak, 2019).

This research includes five EFL students as the study participants. They were selected by using the purposive sampling method. According to, purposive sampling is defined as selective or subjective sampling, indicating a group of sampling techniques that rely on the judgment of the researcher when it comes to selecting the units (Sharma, 2017). The researcher chose those participants because they are enrolled in conversation class; also, from the preliminary observation, they applied code-switching while communicating in the classroom; and most importantly, they had a competent score in conversation class. Those participants were the third-semester students of the English Language Education Department of State Institute of Islamic Studies (IAIN) Takengon of the 2019/2020 academic year.

\section{FINDINGS AND DISCUSSION}

The data analysis was following the result of conversations. 13 EFL students have Gayonese background who took part in three sets of conversations. The interaction predominantly took place in Bahasa, Indonesia. The researcher composed the overall conversation to find out the occurring code-switching and code-mixing. The content of the conversation and the identified code-switching and code-mixing is provided in the following transcript:

\section{Transcript 1}

Participants: Ahmad, Handayani, Rahmad, Ricki

Ahmad: "aku kadang-kadang heran sama anak perempuan ni, kemana-mana bawa bedak, kemana-mana bawa HP, setiap saat selfie"

Handayani: "laki-laki juga kemana-mana bawa rokok"

Ahmad: "tapi enggak merokok di setiap waktu kan, kalian pegang hp nya setiap saat"

Handayani: "because my phone is my life"

Rahmat: "gak bisa hidup tanpa hp ya?"

Handayani: "iya”

Rahmad: "lucu ya, orang gak bisa hidup tanpa makan, tapi ke gak bisa hidp tanpa Hp"

Handayani: "Because everything is here" 
Ricki: "memang ya teknologi kalau salah penggunaannya ya merugikan kalau tepat pengguaannya ya menguntungkan"

Rahmat: "betul kata nenek ku dulu"

Ahmad: “apa memang kata nenekmu mat?”

Ahmad: "suatu saat nanti di masa yag akan datang, akan ada manusia yang tertawatawa sendiri, bicara sendiri dengan apa yang di pegangnya, baru kuingat apa kata nenekku rupanya gara-gara HP haha"

Ahmad: "berarti nenek bisa liat masa depan ya"

Rahmad: "enggakjuga, cuman prediksinya aja"

Ricki: "yeah, and it's happened right now"

Ahmad: "memang udah zamannya"

Handayani: "gara-gara Hp pun heboh, banyak manfaatnya hp, semua jadi cepat dan praktis. bayangkan kalu gak ada hp, kita masih ada dizaman surat-suratan pasti"

From transcript 1 , there appeared types of code-switching and mixing. We can see from conversation by Ahmad "tapi enggak merokok di setiap waktu kan, kalian pegang hp nya setiap saat". And Handayani answered, "because my phone is my life," when Ahmad used the Indonesian language previously, and Handayani later switched the answer to the English language. The code-switching also appears when Rahmad said "lucu ya, oang gak bisa hidup tanpa makan,tapi ke gak bisa hidup tanpa hp" and Handayani switched to English "Cause everything is here". Rahmad also said "enggak juga, cuman prediksinya aja" and then Ricki switched to English and said "yeah, and it's happen rightnow"

\section{Transcript 2}

Participants: Susi, Silviana, Putri, Permai, Sasmita, Ratna

Susi: "suka kali lah kepo in akun orang"

Silviana: "mana ada kepoin, cuma liat aja"

Putri: "pusing kali sama proposal ni lah"

Permai: "kan udah ada kan?"

Putri: "iya, maunya itu dipakek terus untuk skripsi”

Permai: "kan bisa juga"

Putri: "iya tapi susah kali referensinya."

Pemai: "cari judul lain aja"

Putri: "maunya jangan sampe peneltian di sekolah"

Permai: "so"?

Putri: "di kampus aja atau nonton serial movie"

Permai: "kan boleh juga, kan bisa dari aspek bahasa atau yang lainnya"

Sasmita: "kalau aku belum kepikiran kesana, yang penting proposal sama buk yulizar dapat niai B" 
Jurnal As-Salam Vol. 5 No. 2 Juli - Desember 2021: 175 - 184

Imam Munandar, Ramadhani Sukria

Permai: "kan sama aja, nanti juga buat proposal juga".

Sasmita: "iya tapi nanti aja, searang masih pusing"

Permai: "Everything will be ok!"

Silviana: "ké enak, udah ada judulnya bisa usul skripsi terus".

Permai: "belum pasti juga, kalau susah ya ganti lagi”.

Putri: "habis pulang kuliah mampir ke kos ya rat"

Ratna: "lihat dulu lah put, tugas pun banyak kali".

Putri: "makanya kita kerjain sama-sama".

Ratna: "hmmm lihat nanti lah put"

Permai: "tugas apa?"

Ratna: "tugas sama pak Adahri"

Permai: "ooo iya betul, i'm forget".

Furthermore, in transcript 2, there also obviously appeared two types of codeswitching and mixing; intra-sentential and inter-sentential. From the conversation when Putri said "maunya jangan sampe penelitian di sekolah" and Permai said "so?"We can see that Permai switched to English in intra-sentential switching, after Putri said in Indonesia and Permai switched to English. when Putri answered "di Kampus atau nonton serial movie" in here, Putri switched her language to emblematic code-switching, and in the last conversation, when Ratna said "tugas sama Pak Adahri" and Permai responded "ooo iya betul, I forget", Permai used inter-sentential switching in here, because before she spoke Indonesia, "ooo iya betul" and switch to "I forget."

\section{Transcript 3}

Participants: Ahmad, Rahmad, Delvina, Elina, and Linta.

Ahmad: "eh aku titip tas ya, sholat bentar"

Rahmat: “ohh, tumben! ak ada bang berhaga kan?”

Ahmad: "ada banyak!"

Delvina: "ga sholat mad?"

Rahmad: "bentar lagi, tunggu ahmad siap dulu. kalian kenapa gak sholat?"

Elina: "lagi gak bisa"

Rahmad: "alasan, bilang aja malas"

Linta: "Final sama pak adhahri lisan ya?"

Rahmad: "tau dari mana?"

Linta: "dari unit C"

Rahmad: "hmmm, maybe tapi kalau iya, mampus lah aku”

Ipak: "apa aja yang di tanya memangnya?"

Linta: "semua yang dipelajari, semua yang ada dibuku"

Ipak: "o my goodness! bisa gak ya!" 
Linta: "udah lah pasrah aja"

Ratna: "abis ini gak masuk lagi kan?”

Ipak: "enggak lagi"

Ratna: "so, ngapain masih disini?"

Ipak: "nunggu maulida"

Ratna: "kemana dia?"

Ipak: "tempat unit $C$ "

Ratna: "terus ada liat Ricki?"

Ipak: "di mushola tapi kan, sholat"

Ratna: " hmmmm, ok lah, luan ya"

Ipak: "ok Rat"

Rahmad: "hati-hati di jalan, nanti kalau jatuh bangun sendiri haha"

Ratna: "hussss entah apa-apa".

Finally, in transcript 3, all types of code-switching are also apparent. When Linda said, "final sama pak Adhahri lisan ya?" she mixed final to Indonesian language, it meant she asked friends about the final exam with Mr. Adahri, the type of code-switching include to intra- sentential code-switching, and when Linda said "semua yang dipelajari, semua yang ada dibuku" and Ipak responded "oh my goodness! bisa gak ya!" in here she mixed her language in phrase insertion because oh my god have tree word, Rather longer, and when Ipak said "di mushola tapi kan, sholat" and Ratna respond "hmmm,,, ok lah, luan ya" and Ipak said again "ok Rat" they mixing ok, to Indonesian language, so they switched or to Indonesia language.

\section{CONCLUSIONS}

There have been a great number of studies examining bilinguals/multilingual phenomena. One of the most prominent is related to code-switching and code-mixing that usually take place among English learners in the EFL context. Code-switching is defined as changing or mixing certain utterances and codes with another different code in conversation. Most researchers consequently share the opinion that code-switching is not distinct from code-mixing. English learners in EFL context switching language are influenced by many factors, and one of the most common factors is concerning participant features. Furthermore, code-switching is one of the most effective ways which can be utilized by English learners to purposefully convey their intention or thought in conversation. Besides, code-switching helps students avoid miscommunication and to clarify the important message that cannot be clearly explained in one language. Hence, it is obvious that EFL learners would have the opportunity to express their meaningful though or perceptions as bilinguals through a code-switching strategy. 
Jurnal As-Salam Vol. 5 No. 2 Juli - Desember 2021: 175 - 184

Imam Munandar, Ramadhani Sukria

\section{REFERENCES}

Al Heeti, N., \& Al Abdely, A. A. (2016). Types And Functions Of Code-Switching In The English Language Used by Iraqi Doctors In Formal Settings. IJARR, 1(8),10-18 . www.ijarr.in

Ayeomoni, M. O. (2006). Code-Switching and Code-Mixing: Style of Language Use in Childhood In Yoruba Speech Community. In Nordic Journal of African Studies, 15(1), 90-99. http://www.njas.helsinki.fi/pdf-files/vol15num1/ayeomoni.pdf

Bista, K. (2010). Factors of code-switching among bilingual English students in the university classroom. Routledge, UK: Routledge Press

Creswell, J. W. (2014). Research design: Qualitative, quantitative and mixed methods approach (4th ed.). Thousand Oaks, CA: Sage Publication.

Hoffman, C. (1991). Introduction to bilingualism. New York, USA: Longman.

Holmes, J. (2008). An introduction to sociolinguistics (3rd eds.). Harlow, UK: Pearson Education.

Johnstone, B., \& Marcellino, W. M. (2010). Dell hymes and the ethnography of communication. The SAGE Handbook of Sociolinguistics, 3(2), 57-66. https://doi.org/10.4135/9781446200957.n4

Khaerunnisa, L. (2016). An EFL Teacher's Code Switching in a Young Learners' Class. Indonesian Journal of EFL and Linguistics, 1(1), 1331.https://doi.org/10.21462/ijefll.v1i1.

Mabule, D. R. (2015). What is this? Is It Code Switching, Code Mixing or Language Alternating?. Journal of Educational and Social Research, 5(1), 339-350. https://doi.org/10.5901/jesr.2015.v5n1p339

Masna, Y. (2020). EFL Learners' Code-Switching: Why Do They Switch The Language? Englisia: Journal of Language, Education, and Humanities, 8(1), 93-101. https://doi.org/10.22373/ej.v8i1.6662.

Mubarak, Z. H. (2019). the Analysis of Repetition As Part of Lexical Cohesion in Talk Shows. Jurnal Basis, 6(1), 81-94. https://doi.org/10.33884/basisupb.v6i1.1040

Mujiono, M., Poedjosoedarmo, S., Subroto, E., \& Wiratno, T. (2013). Code-Switching In English As Foreign Language Instruction Practiced By The English Lecturers At Universities. International Journal of Linguistics, 5(2), 46-65. https://doi.org/10.5296/ijl.v5i2.3561.

Nilep, C. (2006). "Code-Switching” In Sociocultural Linguistics. Colorado Research in Linguistics, 19(1), 1-22. https://doi.org/10.31235/osf.io/jfecn.

Nooyen, J. (1999). Sociolinguistics by Bernard Spolsky. Issues in Applied Linguistics, 10(1), 90-102. https://doi.org/10.5070/14101005015.

Perry, T. T., Perry, L. A., \& Hosack-curlin, K. (1979). Chapter II Review of the Related Studies. Swansee, UK: Lieberman.

Sadighian, S., \& Rahimi, A. (2011). Code-Switching and Social Prestige: Code Switching among Iranian University Learners. Academic Leadership: The Online Journal 9(3),

23-35.

https://www.researchgate.net/publication/268054934_Functions_of_code switching_among_Iranian_advanced_and_elementary_teachers_and_students

Salah, R., \& Hayek, A. (2016). Arabic-English Code-Mixing by Jordanian University Students. (Doctoral dissertation). Retrieved from https://researchdirect.western Sydney.edu.au/islandora/object/uws:36867/datastream/PDF/download/citation.p df.

Sharma, G. (2017). Pros and cons of different sampling techniques. Harlem, U.S.A: 
Stafford Press.

Suganda, L. A., Loeneto, B. A., \& Zuraida, Z. (2018). Teachers' Use of Code Switching In An English As A Foreign Language Context In Indonesia. Journal of Linguistic and English Teaching, 3(2), 111-126. https://doi.org/10.24903/sj.v3i2.202.

Sugiantari, N. P. A. Y. (2018). Code-Switching and Code-Mixing By The Government Of Bali. Jurnal Ilmu Bahasa, 4(2), 107-112. https://doi.org/10.22225/jr.4.2.847.107112.

Susan. G. (1998). The Practical economy of code choice in M.Heller (ed), CodeSwitching: Anthropological and sociolinguistics perspectives. New York, USA: Mouton de Gruyter.

Susidamaiyanti. (2018). The Communication Strategies Employed By Male And Female Students. Jurnal Assalam, 2(3), 109-117. https://doi.org/10.37249/assalam.v2i3.106.

Trisnawati, I. K. (2017). Maintaining The Identity Of Bilingual Individuals In Multicultural/Multilungual Settings. Jurnal Englisia, 5(1), 8-16. http://dx.doi.org/10.22373/ej.v5i1.1660.

Wahyu, T., Mukti, P., \& Muljani, R. (2016). Code-Switching In The Instructions Of English Language Education Study Program Lecturers. LLT Journal, 19(1), 46-60. https://doi.org/10.24071/llt.2016.190105.

Wijayanti. (2014). Bahasa Indonesia/English Code Switching at USBI The Sampoerna University. Jakarta, Indonesia. Unpublished Thesis. https://doi.org/10.15242/icehm.ed1214069.

Yusuf, Y. Q., Fata, I. A., \& Chyntia. (2020). Types Of Indonesian-English CodeSwitching Employed In A Novel. Kasetsart Journal of Social Sciences, 41(1), 208213. https://doi.org/10.1016/j.kjss.2018.02.004. 